Volume 2

Number 2 Popular Culture and Markets in

Turkey

\title{
Politics, Culture and Media: Neo-Ottomanism as a Transnational Cultural Policy on TRT El Arabia and TRT Avaz
}

\author{
Y. Gökçen Karanfil \\ Izmir University of Economics \\ D. Burcu Eğilmez \\ Independent researcher
}

Follow this and additional works at: https://digitalcommons.uri.edu/mgdr

Part of the Broadcast and Video Studies Commons, International and Intercultural Communication Commons, International Relations Commons, Mass Communication Commons, and the Other Political Science Commons

\section{Recommended Citation}

Karanfil, Y. Gökçen and Eğilmez, D. Burcu (2017) "Politics, Culture and Media: Neo-Ottomanism as a Transnational Cultural Policy on TRT El Arabia and TRT Avaz," Markets, Globalization \& Development Review: Vol. 2: No. 2, Article 4. DOI: 10.23860/MGDR-2017-02-02-04

Available at: https://digitalcommons.uri.edu/mgdr/vol2/iss2/4

This Article is brought to you for free and open access by DigitalCommons@URI. It has been accepted for inclusion in Markets, Globalization \& Development Review by an authorized editor of DigitalCommons@URI. For more information, please contact digitalcommons-group@uri.edu. 
Politics, Culture and Media: Neo-Ottomanism as a Transnational Cultural Policy on TRT El Arabia and TRT Avaz

\section{Cover Page Footnote}

The authors would like to thank Research Assistant Aytunç Erçifci for his valuable contributions in the data gathering process of this research. 


\section{Markets, Globalization \& Development Review}
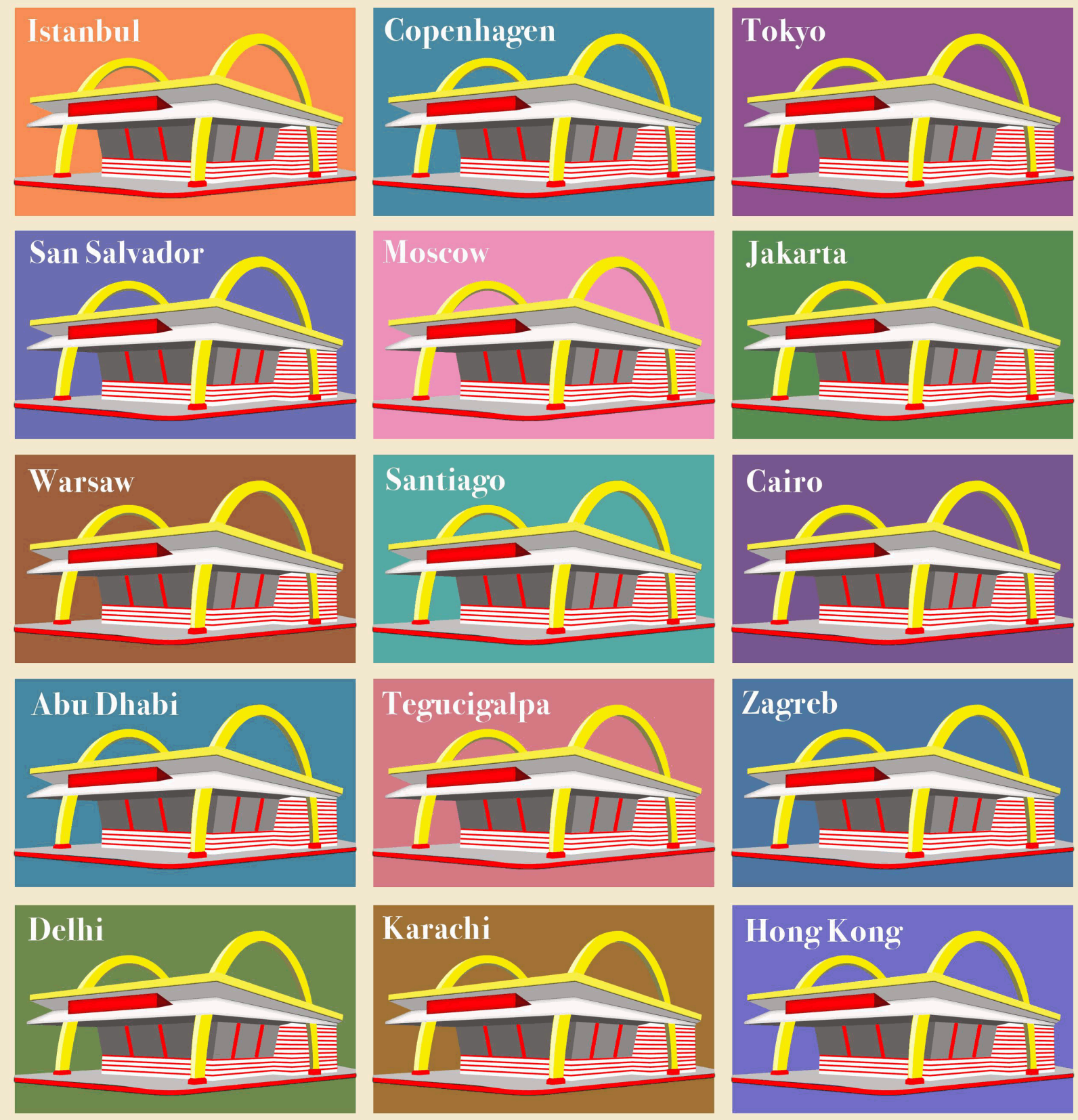

This article is available in Markets, Globalization \& Development Review: https://digitalcommons.uri.edu/mgdr/vol2/ 


\section{Politics, Culture and Media:}

\section{Neo-Ottomanism as a Transnational Cultural Policy on TRT El Arabia and TRT Avaz}

\section{Introduction}

In the very first issue of Markets, Globalization \& Development Review (MGDR), Dholakia and Atik, as the founding editors, set out to frame the critical optic through which MGDR formulates the three concepts that make up the title of the journal. When referring to the cultural component of globalization, they argue that "globalization of culture, while facilitated strongly by the big media conglomerates that are closely allied to and controlled by global centers of finance, nonetheless offers opportunities for masses of ordinary people to exchange information and ideas" (2016, p. 4). When exploring the topography of the market, they suggest that MGDR is not only open to, but also encourages the exploration of markets in their non-orthodox forms, including "non-market forms of making goods and services available to people" (2016, p. 2). This article speaks from the intersection of these claims to a critical understanding of the processes of globalization and the concept of the market. In our attempt to scrutinize the ways in which the public service broadcaster of Turkey, as a nonwestern actor, works towards forging a transnational cultural sphere among the Arab-speaking Islamic viewers, we inherently point at both an unexpected set of cultural flows in the global media ecology, and a noneconomically driven imagination of a market of viewers. Taking these nonconventional conceptions of markets and globalization as our starting point, we aim to analyze in this article how the historical overlap of the technological developments in the field of communications and the rejuvenation of neo-Ottomanist ideological discourse in Turkey has paved the way towards the transformation of the Turkish Radio and Television (henceforth TRT) from a national to a transnational broadcaster. In doing so, we take as our case TRT Avaz and TRT El Arabia, the two transnational expansions of TRT, and shed light on how these two channels are deployed by the Justice and Development Party (from here on JDP) government to exert cultural presence in the Islamic and Arabic speaking neighboring regions of Turkey.

As the public service broadcaster of the country, TRT was established in 1964. It opened its first television channel in 1968, and functioned as Turkey's sole television station until the beginning of 1990s, when commercial broadcasters started emerging. Despite having been 
established as an autonomous institution, the station lost its autonomy during the constitutional change in 1972, and it has become increasingly commonplace to regard TRT as a tool of propaganda in the hands of the ruling governments. Furthermore, since its establishment and early days, TRT has almost always been deployed by the country's ruling elite to nationalize and modernize the public (Çaplı 1996). This nationalizing and modernizing elitist agenda prevailed as a transcendent discourse throughout the institution's history. In this sense, the reinforcement of Republican ideals, and "Turkish cultural values" through its broadcasts has always been a part of its agenda.

Despite this "national" agenda still being prevalent, we argue that particularly within the last decade, another agenda has become apparent in the mission of this public service broadcaster. Today TRT is being mobilized by the JDP government to increase the visibility of Turkey in the Middle East and to establish a cultural presence in the region. While it is not the first time that TRT has engaged in broadcasts targeting viewers beyond the borders of Turkey, it is our contention that the current expansions of TRT targeting audiences, mainly in the MENA (Middle East and North Africa) region, deserve special attention - due both to the nature of these broadcasts and their historical overlap with the neo-Ottomanist agenda in JDP government's domestic and foreign policies. This agenda is revealed particularly by the two expansions, namely TRT Avaz and TRT El Arabia. Hence our aim in this article is to shed light on the ways in which these two channels act as transnational agents of the JDP government in disseminating a neo-Ottomanist discourse among the geographies perceived as the hinterlands of the former Empire.

There have been various discussions in the literature with regards to the relation between the deployment of popular media products and Turkey's attempts at exerting soft power and a neo-Ottomanist discourse in its neighboring regions. Some of the most recent and stimulating studies in this area can be cited as Alankuş and Yanardağoğlu 2016; AlGhazi and Kraidy 2013; Buccianti 2010; Kraidy and Al-Ghazi 2013; Yanardağoğlu and Karam 2013; Yörük and Vatikiotis 2013. Research on the role of broadcast media products in Turkey's attempts at fostering soft power and disseminating neo-Ottomanism in the region (particularly the region of MENA), generally focuses on two main areas: a-) the Turkish TV drama series and $b-)$ on the degree of success of these TV dramas in fostering a cultural presence in the region. A contextualization - on a more macro level -of the emerging sociopolitical conjuncture in these outer regions, even if not completely neglected, seems to be less of a concern. 
It is our contention that in order to better understand the recent developments in Turkish transnational broadcast media within the context of the changing Turkish foreign cultural policy, there is a need for detailed analysis a-) on the dynamics between politics, culture and media with relation to JDP's deployment of media products as forms of soft power, and $b-$ ) on how the transnationalization of the global media environment has contributed to these attempts with reference to the transnational expansions of TRT. Following this line of thought, with an attempt to contribute to the ongoing discussions in the literature, what we aim to do in this article is to point at how the establishment of TRT's new transnational expansions may be traced to the recent transformations in the global media ecology, and also the changing cultural policies, both domestic and foreign, of the JDP government.

To shed light on the backdrop of events that have triggered TRT's transnational agenda, we focus on the historical coincidence of three phenomena; the increased ease in the use of satellite related communication technologies, the emergence of a neo-Ottomanist ideology embodied in the JDP government, and the founding of new expansions of TRT. These factors, we argue, have paved the way towards the emergence of a neo-Ottomanist transnational agenda within TRT. We are concerned with better understanding an unprecedented transformation within both the structure and the discourse of Turkey's public service broadcaster, with relation to the changing political and cultural dynamics in the region. Our discussion therefore, is related not so much to the success or failure of AKP's foreign policy initiatives and the involvement of popular media products therein, but rather, to the ways in which a strictly "national" public service broadcaster is being mobilized as a transnational cultural agent of the state, and burdened with a transnational agenda that contradicts its decades long broadcasting politics.

\section{Developments in ICTs and the Emergence of Transnational Media Cultures}

In order to fully come to grips with the transnationalization of TRT, one needs to understand the impact developments in the telecommunications field over the last two decades has had on this process. Therefore, what we would like to do in this section is to shed light on these developments, which we believe will complement our understanding of the transformation in TRT.

There is an abundant use of the term transnationalism in the literature, not only in the social sciences in general, but also in the field of media and communication. While it is not a completely new concept, its 
use has proliferated over the past two decades and has become a key concept in migration, globalization and global media studies. The legitimacy of the use of the term lies in the argument that contemporary identities and activities (social, economic, political) of social life can no longer be fully explained with concepts that are inherently national. Similarly, the use of the term in media and communication studies refers to the emergence of media ecologies that can no longer be bound by national boundaries. Information and communication technologies crisscross national boundaries with relative ease, creating the possibility for increased and intensified forms of communication (Panagakos and Horst 2006, p. 113). Hence, these new technologies foster new media spheres and flows that seek audiences transnationally, and forge transnational cultural formations. The anchor of these media flows, audiences and cultural formations are no longer national references.

Therefore, despite the fact that the emergence and the early years of broadcast media have been strictly national, it is fervently argued that today we are experiencing a more sophisticated media model that scholars refer to as transnational (Aksoy and Robins 2000, 2003; Chalaby 2003, 2005; Christensen 2013a, 2013b; Christensen and Jansson 2013; Cunningham and Sinclair 2000; Karim 1998; Straubhaar 1997; Vertovec, 2001, 2009). Tracking the evolution of international communications over the past decades, Jean Chalaby (2005) states, "the transnationalization of global media at the beginning of the 21st century can be comprehended as the third phase in a succession of paradigm shifts in the evolution of international communication from the mid-19th century onwards" (p. 28).

According to Chalaby (2005), the first phase of this evolution in the media environment can be labeled as the internationalization of communications. While internationalization of communications and broadcasting accelerated dramatically during 1970s and 1980s, as Chalaby reminds us, it was the invention of the telegraph that lay at the roots of these developments. A trend towards an increase in the internationalization of media flows started with governments' realization of the importance of new communication technologies during 1980s. International broadcasting was seen as an effective tool by governments to disseminate their national presence around the world.

Chalaby proposes that the second phase in the transformation of media was the globalization of media flows (2005). The globalization of communication started at the beginning of the second half of the $20^{\text {th }}$ Century. The global media model is characterized by giant media organizations and conglomerates expanding their worldwide reach through deregulation and trans-border integration. As the processes of 
globalization accelerated, the unequal distribution of (and access to) media resources also proliferated, leading to the emergence of a global media environment dominated by a handful of western media moguls with newly acquired trans-border reach.

According to Chalaby (2005), the transnationalization of media emerged with the turn of the $21^{\text {st }}$ Century, as the third paradigm in the evolution of international communication. In legitimizing the distinction in these three paradigms in international communication, Chalaby suggests,

The first phase is typified by international expansion, telegraph companies and news agencies joining up previously unconnected parts of the world. The globalization stage is characterized by worldwide integration and the formation of an electronic global village... The distinctive feature of the current era is cosmopolitanization. Once, international communication reinforced nation-states, then it linked them together, and today it is transforming their very fabric (2005, pp. 31-32).

Therefore, the transnationalization of media can be differentiated from the internationalization of media in that the content in transnational media is not dominated by national media products, and the incentive is not simply to disseminate a national agenda on a trans-border scale. As Aksoy and Robins argue, through transnational media consumption, viewers "extend their horizons of experience of involvement. ...moving beyond the frame of national society" (2000, p. 36). On the other hand, transnational media is also differentiated from global media, as it is characterized by the proliferation of non-Western novel media organizations that are empowered by trans-border reach, which in turn, fosters sophisticated counter media flows, challenging the conventional unidirectional "from the west to the rest" reach of globalization.

The transnational media paradigm, therefore, can be defined as a media environment that cultivates media organizations with trans-border reach, which broadcast from their non-Western positions, and are not necessarily bound by national references (whether in terms of audience, content and ownership). These transnational media organizations form trans-border communalities and markets (that are not necessarily national) among populations dispersed around the world. Taking these arguments as our point of departure, we suggest that today, the expansions of TRT have become truly transnational, in that they don't target audiences formed only around Turkish ethnicity, nationality, language or culture, but rather their aim is to also reach transnationally imagined viewers/markets perceived to be collectively gathered around what can be referred to as 
neo-Ottoman culture and morals. There is an apparent de-nationalization in the broadcast politics of these channels, and the vacuum is filled with a transnational belonging romanticized around neo-Ottomanist and particularly Islamist values. Therefore, we argue, TRT is no longer a national or an international broadcaster per se, but harbors a prevalent transnational agenda as well.

We claim that today as a public service broadcaster with transnational market in mind, TRT aims to contribute to a transformation in the Middle Eastern broadcasting sphere through fostering a transnational communality among populations living in the perceived hinterlands of the former Ottoman Empire. We label the broadcasts of TRT's expansions as transnational, because they broadcast as alternative media outlets (to global media giants such as CNN, BBC etc.), their broadcasts transcend national borders, and they imply a trans-border collectivity not around national references, but around the notion of neo-Ottomanism as a transnational form of identification. TRT has come to hold a position as a broadcaster, unprecedented in its history. While on the one hand, it remains a state-owned and run institution, on the other, it is engaging in broadcasts that target non-Turkish citizens beyond the borders of Turkey - in terms of geography, culture, and language.

\section{Neo-Ottomanism, Post-National Identity and JDP Politics}

One cannot thoroughly analyze the transnationalization of TRT without understanding the idea of neo-Ottomanism, which started to characterize Turkish domestic and foreign politics since the time of Turgut Özal. NeoOttomanism, or roughly defined, the revival of the Islamic imperial past in Turkish present, is the key to comprehending the new identity formulation of Turkey at home and abroad. The formation of this new identity that Yavuz aptly labels as "trans-ethnic" or "post-national," is explanatory also in the concomitant transnationalization of TRT (Yavuz 1998, p. 32; 2016). In this respect, to establish the links between the rise of neo-Ottomanism, post-national identity and the not coincidental transnationalization of TRT, in the following section we attempt to briefly situate the idea of neoOttomanism into Turkish history with a particular emphasis upon its burst as a governing tool particularly under the rule of JDP.

It was in the post-mid-1980 period that Turkish state was forced to redefine itself due to the changing requirements of domestic political, economic and international developments. The first appearance of contradictions in militant secularism and ethno-nationalism characterizing the Kemalist modernization project emerged with the rising identity claims of Kurds. Secondly, the period witnessed a consolidated opposition of pro- 
Islamists. As an alternative to the idea of homogenous Turkish nation and militant secularism, Özal pragmatically adopted the idea of neoOttomanism with a particular emphasis on its "pluralism" in order to govern identity claims and dissent of pro-Islamists in the country (Yavuz 2016, p. 444; Çolak 2006). The idea of neo-Ottomanism was also crucial for Özal's project of neo-liberalism. In his search for markets in the Middle East, Özal successfully mobilized the idea of the shared Ottoman past and Islam (Altunışık 2009, pp.181-182). Along with domestic developments and economic concerns, it is needless to say that the ending of the Cold War and the changing balances due to the collapse of the bipolar world order also deemed necessary to revise Turkey's identity formulated in Kemalist lines (Yavuz 1998, p. 33). Thus, the idea of neo-Ottomanism well served the primary political and economic requirements of the period. However, it should be noted that although Özal emphasized a shared past and culture both in the domestic and international spheres, he also kept his commitment to Kemalist secularism and the West, all the while pragmatically using its relations with the Middle East to strengthen Turkey's hand in its relations with the United States and the EU (Altunışık 2009, pp. 182-183; Öniş 2011, p. 49; Yavuz 2016, p. 444).

The coming of JDP to power in 2002 with the discourse of conservative democracy signaled the burst of the idea of neo-Ottomanism in the domestic and international spheres. Although the rejuvenation of neo-Ottomanism is discussed with reference to the rule of JDP, we should also note the efforts for the revival of Ottoman-Islamic past after Özal and before JDP. The success of Welfare Party (Refah Partisi) in 1995 elections and its partnership in the coalition government for example, is pointed out as "the first time" when "the Turkish Republic had a prime minister whose identity and political philosophy explicitly was based on the Ottoman-Islamic heritage" (Yavuz 1998, pp. 20-22). Moreover, it is also noted that the "dual identity of Turkey" or the Ottoman legacy was emphasized in foreign policy by İsmail Cem between 1997-2002 (Altunışık 2009, pp. 184-85; Öniş 2011, p. 47). What the claim of conservative democracy differed from Özal's neo-Ottomanism was the increasing stress on the Islamic identity of Ottomans as the main component of new Turkey's identity. "Ottoman motifs in the fields of art, design, architecture, fashion, literature, film, and television", moreover "festivals celebrating Ottoman milestones like the conquest of İstanbul," and "new bank notes upon which Ottoman figures are emblazoned" have become the primary reflections of this new policy in social and cultural spaces (Fisher-Onar 2011, p. 470). The parallel shift in foreign policies towards a more active involvement in the Middle Eastern region via soft power, on the other 
hand, became visible particularly after 2007. The reasons driving this turn cannot be explained with the conservatism and Islamic identity of the JDP per se. New ambiguities in the international relations also need to be pointed out. Two major issues prevail in the related literature. Firstly, the relations with the United States had to be redefined particularly after the invasion of Iraq by the USA in 2003, which was taken as a threat to the security concerns of Turkey regarding the Kurdish issue (Oğuzlu 2008, pp. 7-10; Oğuzlu 2007, p. 86). Secondly, a snag in relations with the EU was another factor for Turkey's growing assertiveness in the Middle East (Oğuzlu 2008, pp. 10-13; Oğuzlu 2007, pp. 86-87; Öniş 2011, pp. 53-54). Additionally, the questioning of "American or Western-dominated globalization" after the global crisis of 2008 further contributed to the shift of Turkey's move to a more active position in the Middle East region (Öniş 2011, pp. 54-55). Finally, the transformation of the negative perception of Turkey by the Middle Eastern countries, that characterized the post-War period, accelerated during the rule of JDP. JDP became a model for the possibility of coexistence of Islam, democracy, secularism and good relations with the West (Altunışık 2008, pp. 43-45; Oğuzlu 2007, p. 89; Öniş 2011, p. 57). Characterized by these main international developments, particularly after the post-2007 period, "strategic depth" and "zero problems with neighbors" understanding of Ahmet Davutoğlu and the support provided by Abdullah Gül and R. Tayyip Erdoğan contributed to further mobilization of activism in the Middle East with the neo-Ottomanism discourse (Öniş 2011, p. 58).

Ahmet Davutoğlu, an academician, foreign policy adviser to Abdullah Gül and R.Tayyip Erdoğan between 2003-2009, foreign minister between 2009-2014 and Prime Minister between 2014-2016 has been the key figure in the formulation of JDP's foreign policy. His book Strategic Depth published in 2001 became the guide for Turkey's foreign policy and scholars who attempted to comprehend its contours. What Davutoğlu offers as the logic of new foreign policy is the unification of "Turkey's historical and geographic depth with a rational strategic planning" (2010, p. 10). In this formulation, identity, time and space consciousness are regarded as prerequisites for historical existence and contribution to humanity (Ibid: 30-31). In this respect, Ottoman background and Turkey's strategic geographical potential (past and present) is emphasized by Davutoğlu as the criterions which not only constitute Turkey's identity but also give it responsibility for an active role in foreign relations in the former territories of the Ottoman Empire. The following statement summarizes the new transnational security concerns and thus the foreign policy of new Turkey: 
It is impossible for Turkey, which was born on the historical and geopolitical ground of the Ottoman Empire, to think and plan its defense only within its own borders. This historical legacy may lead to de facto situations beyond the borders of Turkey at any time, in which she may need to become involved (Davutoğlu 2010, p. 41).

Davutoğlu proposes that Turkey should adopt a new identity and active foreign policy in its hinterland by emphasizing "common historical ties" and "Islam" with Balkan countries and Caucasia (2010, pp. 55,121), and its "cultural prestige" to reorganize the relations with Arab countries (2010, p. 57). It is obvious that his criticisms are based on the Kemalist modernization project that chose the West as its ally, ignored its political culture based on geopolitical and historical background, and remained passive in the MENA region (Ibid: 83,93). In line with these arguments, in the foreign policy under the JDP government, we observe an emphasis upon the "importance of history, culture, Islamic civilizational identity" and an "active involvement in regional conflicts", which do not necessarily exclude "compatibility with the West" (Altunışık 2009, p. 193). As agreed by the relevant literature, this policy orientation indicates soft power that is "evident in the preferences for instruments like trade, cultural and educational exchanges, and multilateral platforms (Fisher-Onar 2011, pp. 471-72).

We, in this respect, follow the discussions that comprehend neoOttomanism as a key idea which is "about constructing a new 'national' (not nationalist) identity and translating it into foreign policy by using historical, cultural and religious ties to former Ottoman territories" (Yavuz 2016, p. 443). We, moreover, argue for a strong relationship between "trans-ethnic" or "post-national" identity formulations embedded in the idea of neo-Ottomanism and the paralleled transformation of TRT as a transnational apparatus in this endeavor (Yavuz 1998, p. 32; 2016).

\section{TRT: An Unexpected Journey of a Public Service Broadcaster}

Like the phenomenon of broadcasting itself, TRT as a public service broadcaster has emerged as a national institution when first established in 1964. Kaptan and Karanfil suggest, "as in many developing countries, public service broadcasting in Turkey, as a state-sponsored network, was introduced as part of a nationalist agenda in the process of citizen forming" (2013; p. 2332). Therefore, TRT was not only a national institution, but perhaps as importantly, a nationalizing apparatus as a means of forging a modern, national audience that acted in line with the westernizing ideals of the ruling statist elite in Turkey. In this sense, until 
the last decade of the 20th century, the scope of TRT's broadcasts had strictly been national. While TRT has always been a tool of propaganda for the governments in power in Turkey, the case has more often than not been that the ideologies of the governments in power have been in line with the "secularist", "modernist", "nationalist", and "Westward" ideals of the state. In this sense, even when engaging in trans-border broadcasting through its expansions in 1990s and early 2000s (TRT INT, TRT Türk, TRT Avrasya), TRT has at the most been an internationalizing agent of the state.

In 1990 TRT launched its first transnational channel TRT INT Avrasya to target Turkish migrants living in Europe. Soon after, in mid 1990s, TRT INT Avrasya got separated into two different channels as TRT INT and TRT Avrasya. TRT INT was established to meet the needs of Turkish speaking populations dispersed around the world by offering them entertainment and information from their homeland. It was hoped that this channel would also help them reconnect with their country of origin. The common denominator here was Turkishness and Turkish language. Therefore, TRT's attempts to expand its reach across the borders of Turkey through TRT INT were an endeavor to disseminate values of "Turkish culture" to Turkish expatriates dispersed around the world. The broadcasting goals of the station were listed on its official web page as:

- To strengthen the ties between our citizens living overseas and Turkey and Turkish culture.

- To represent all aspects of Turkey and Turkish nationals; to raise their educational and cultural levels.

- To help Turkish nationals around the world preserve their language, religion, morals, unity and solidarity.

- To maintain their connections with the Turkish Republic by strengthening their spirit and showing how their various problems can be resolved.

- By introducing the cultures of their countries of residence, helping them live in harmony with their host nations.

- To keep our citizens informed by countering false and harmful propaganda like that from the Armenians and other destructive, separatist, and reactionary groups that wish to do our nation harm (Karanfil 2011).

TRT Avrasya on the other hand was founded on the basis of reaching the Turkic Republics who gained their independence after the collapse of the Soviet Union. Again, the broadcasts were targeting audiences perceived by the Turkish state to be a part of the Turkish ethnic community and speaking "variations" of the Turkish language. When 
referring to the mission of TRT Avrasya, Aksoy and Robins claim, "TRT as the agent, effectively, of the Turkish state - has been involved in a systematic strategy... It is a strategy that has aspired to connect together the imagined community of Turks at a global scale" (2000, pp. 346-47). They further argue that,

The whole project was clearly a political rather than a commercial one it tended to promote wider Turkish interests and heavily backed - both financially and ideologically - by the Turkish government. This channel was a weapon of foreign policy in a newly reactivated and strategically important geopolitical region (2000, pp. 346-7).

Therefore, it would be unfair to argue that TRT's trans-border broadcasts started with the JDP government during the last decade. In fact, as discussed previously, the rise of Neo-Ottomanism under Turgut Özal overlaps with the emergence of trans-border broadcasts. However, there has been a radical transformation in the broadcast politics of TRT's cross border expansions with the turn of the last decade and they deserve special attention.

TRT engaged in broadcasts targeting the Arab speaking and Islamic world for the first time in 2010 with the establishment of TRT-ETTurkiyye (later TRT El Arabia). A year before that, in 2009, TRT Avaz was established to cater to the needs of the populations of the post-Soviet Turkic Republics in the region. What is important to realize here is that, these expansions of TRT that target viewers in the Middle East and the Arab world emerged in line with the rise of neo-Ottomanist tendencies in Turkish politics. For the first time in its history, modern Turkey had turned its face to the Islamic based societies in its neighborhood and TRT was deployed to exert a cultural presence in the region. Unlike previous transnational expansions of TRT, in none of these newly emergent broadcasts was Turkishness Turkey (as an ethnicity or nationality) or cultural values and norms of the Turkish Republic at the center. The perceived common denominator was formulated as the Ottoman and Anatolian cultural history, values and morals.

Therefore, the broadcast policies of TRT Avaz and TRT El Arabia deserve being distinguished from former cross-border channels of TRT, because they aim at exerting a cultural presence in the region not through common language and ethnicity but through common cultural values of which Islam and a common shared Ottoman past form the pinnacle. It is possible to observe this shift in the broadcasts of TRT's expansions by simply looking at a-) how these TV stations define themselves, their missions and visions and b-) what make up the content of their 
broadcasts. While it is beyond the scope of this article to carry out detailed content or policy analysis, it is our contention that by reflecting on the names and textures of programs and by highlighting statements from missions and visions of these channels, we will be able to better articulate our argument as to the neo-Ottomanist tendencies visible in TRT's new transnational expansions.

In our analysis of the broadcast content of the stations, we initially looked at one week's streaming for each station between the $3^{\text {rd }}$ and the $9^{\text {th }}$ of August 2016. Then, to make sure that there is a consistency and continuity in the nature of the programs being broadcast over different periods of time, we looked at another two weeks of broadcasting between $2^{\text {nd }}$ and the $8^{\text {th }}$ of November, and $6^{\text {th }}$ and $11^{\text {th }}$ of March. By doing this, we have, in effect, looked at three different time periods over a total of six months' time. In cross referencing the program flows of the three weeks dispersed over six months it became apparent that there was no change in the program flows on an ideological level. In fact, most of the programs we have observed in the initial screening were still being broadcast in our second and third screening periods. Documentary series and cultural programs that had come to an end were replaced by new programs of the same nature.

\section{TRT Avaz}

As stated on the official website of TRT Avaz, "the station was established in 2009 to reach a population of approximately 250 million, dispersed in a geography ranging from the Balkans to the Middle Asia and the Middle East to the Caucuses" (http://www.trtavaz.com.tr/). Prior to being named TRT Avaz, the station was initially established as TRT Avrasya in 2001 which was later renamed as TRT Türk. Particularly after the station received its current name in 2009, there was a dramatic change in the content of the broadcasts. The broadcasts changed from having an "ethno-nationalist" focus to becoming much more culture and geography oriented. We will discuss this in more detail in the coming pages. It is argued that the station "aims at disseminating Turkish culture and Anatolian cultural values to populations speaking Turkish, Azeri Turkish, Kazak, Kırgiz, Üzbek, and Türkmen living in 27 different countries in the relevant geography" (http://www.trtavaz.com.tr/). According to the mission of TRT Avaz, it strives to be the "one channel where all these populations meet and find values from the common shared Turkish culture". It may be worth mentioning here that the word "avaz" literally means "voice" in a number of Turkish dialects. In line with the meaning of its name, TRT Avaz, claims to "give voice to" or "be the voice of" populations living in the above-mentioned geographies. At first glance there seems to be a direct 
focus in the mission and vision statements of TRT Avaz on the notion of Turkishness and Turkish culture. However, when one looks at the content of the broadcasts more closely, it becomes apparent that the focus of most of the programs broadcast on the station is on Anatolia as a geography and Ottoman/Islamic history and culture as an allencompassing heritage.

The table below gives an overall picture of the schedule and screening times of programs we have chosen which display signs of neoOttomanist discourse. The table shows programs broadcast within a period of one week, between the dates 02.11.2016 and 08.11.2016.

Table 1: Broadcast schedules of relevant programs in TRT Avaz

\begin{tabular}{|c|c|c|c|c|c|c|c|}
\hline Program Names & 02.11 .16 & 03.11 .16 & 04.11 .16 & 05.11 .16 & 06.11 .16 & 07.11 .16 & 08.11 .16 \\
\hline $\begin{array}{l}\text { Anadolu'nun Sıcak Yüzleri } \\
{ }^{*} \text { Warm Faces of Anatolia }\end{array}$ & $20 \mathrm{~min}$ & $20 \mathrm{~min}$ & & & & $20 \mathrm{~min}$ & $20 \min \times 2$ \\
\hline $\begin{array}{l}\text { Derin Kökler } \\
{ }^{\star} \text { Deep Roots }\end{array}$ & $5 \min \times 4$ & $5 \min \times 4$ & $5 \min \times 4$ & $5 \min \times 3$ & & $5 \min$ & $5 \min \times 4$ \\
\hline $\begin{array}{l}\text { Rusya Müslümanları } \\
{ }^{\star M u s l i m s ~ o f ~ R u s s i a ~}\end{array}$ & & & & $30 \mathrm{~min}$ & & & $30 \min \times 2$ \\
\hline $\begin{array}{l}\text { Sultanların İinde } \\
\text { *In the Footsteps of } \\
\text { Sultans }\end{array}$ & & $10 \mathrm{~min}$ & $15 \mathrm{~min}$ & & & $10 \mathrm{~min}$ & $10 \mathrm{~min}$ \\
\hline $\begin{array}{l}\text { Yüzyıllık Hikayeler } \\
{ }^{\star} \text { Century Old Stories }\end{array}$ & & & & & & & $30 \mathrm{~min}$ \\
\hline $\begin{array}{l}\text { Çanakkale'de Unutulan } \\
\text { Avazımız } \\
\text { `Our Forgotten Avaz in } \\
\text { Çanakkale }\end{array}$ & & & & & $35 \mathrm{~min}$ & & $30 \min$ \\
\hline $\begin{array}{l}\text { Tarihte Bugün } \\
* \text { In History Today }\end{array}$ & $5 \min \times 2$ & $5 \min \times 2$ & $5 \min \times 2$ & & & $5 \min$ & $5 \min \times 2$ \\
\hline $\begin{array}{l}\text { Devrialem } \\
{ }^{*} \text { Around The World }\end{array}$ & $20 \min \times 3$ & $20 \min \times 3$ & $20 \min \times 3$ & $90 \min \times 2$ & $95 \min$ & $20 \min \times 3$ & $20 \min \times 3$ \\
\hline $\begin{array}{l}\text { Balkan Gündemi } \\
{ }^{*} \text { The Balkan Agenda }\end{array}$ & $40 \min \times 2$ & $40 \min \times 2$ & $40 \min \times 2$ & & $45 \min \times 2$ & $40 \min \times 2$ & $40 \min \times 2$ \\
\hline $\begin{array}{l}\text { Bir Kent Hikayesi } \\
{ }^{\star} A \text { City Story } \\
\end{array}$ & & & & & & & $30 \mathrm{~min}$ \\
\hline $\begin{array}{l}\text { Sadece Bizde Var } \\
{ }^{\star} \text { Only We Have It }\end{array}$ & $20 \mathrm{~min}$ & & & & $15 \min$ & & \\
\hline $\begin{array}{l}\text { Memleket Yemekleri } \\
{ }^{*} \text { Foods of the Homeland }\end{array}$ & $35 \mathrm{~min}$ & & & & & & \\
\hline $\begin{array}{l}\text { Türk Lezzeti } \\
{ }^{*} \text { Turkish Delight }\end{array}$ & $25 \mathrm{~min}$ & & & $10 \mathrm{~min}$ & $15 \mathrm{~min}$ & & \\
\hline $\begin{array}{l}\text { Ortak Miras } \\
{ }^{*} \text { Common Heritage }\end{array}$ & $30 \mathrm{~min}$ & & & & & & \\
\hline $\begin{array}{l}\text { Sohbet-name } \\
{ }^{*} A \text { Warm Chat }\end{array}$ & & & $30 \min \times 2$ & & & & \\
\hline $\begin{array}{l}\text { Necmettin Nursaçan'la } \\
\text { Rahmet Kapısı } \\
\text { `The Door of Benediction } \\
\text { With Necmettin Nursaçan }\end{array}$ & & & $50 \mathrm{~min}$ & & & & \\
\hline $\begin{array}{l}\text { Üç Kıtanın Son Hükümdarı } \\
\text { •The Last Emperor of the } \\
\text { Three Continents }\end{array}$ & & & & & $40 \mathrm{~min}$ & & \\
\hline $\begin{array}{l}\text { Seyahatname: Evliya } \\
\text { Çelebi'nin İinde }\end{array}$ & & & & & & $30 \min \times 2$ & \\
\hline
\end{tabular}




\begin{tabular}{|l|l|l|l|l|l|l|l|}
\hline $\begin{array}{l}\text { *Itinerary: In the Footsteps } \\
\text { of Evliya Çelebi }\end{array}$ & & & & & & & \\
\hline $\begin{array}{l}\text { Tibb-I Nebevi } \\
\text { *Islamic Medicine }\end{array}$ & & & $30 \mathrm{~min}$ & & & & \\
\hline Total Duration & $\mathbf{3 0 0}$ min & $\mathbf{2 0 0}$ & & & & & \\
\hline
\end{tabular}

While some of these programs focus on Islam as a defining tenet in the Ottoman culture, others emphasize the sultanate and the Anatolian culture, while some others focus on Istanbul as the capital of the Empire as reference points to neo-Ottomanism. In our analysis we have opted to focus on these three themes as markers of neo-Ottomanist discourse. In order to justify why we have chosen to focus on Islam, Anatolian culture, and Istanbul as themes that represent neo-Ottomanism, it is necessary to briefly recall how neo-Ottomanism has been defined in the literature. The emergence of the term with the prefix of neo is traced back to 1985, when David Barchard in his book, Turkey and the West coined the term (Yavuz 2016, p. 443; Yanık 2011, p. 84). In this characterization of the term, two dimensions came into prominence: "consciousness of the imperial Ottoman past" and "Turkey's turn to the Middle East" (Ibid.). The first dimension is about revitalization of the Ottoman past in the Turkish present. Accordingly, it is about the revival of particularly religious and cultural characteristics of the Ottoman Empire in the political, cultural and social domains. The second dimension is about emphasizing this shared past and Islamic identity in relations with the Middle Eastern countries. Yavuz (2016) aptly summarizes the common themes in the related literature by framing the "discourse activities the neo-Ottomanist discourse engages":

[c]onstructing certain aspects of the past, aiming to deconstruct the Kemalist Republican's conception of identity and society; offering a more discursive instrument to reach out to ex-Ottoman societies to promote the market for Turkish goods and, more broadly, sociopolitical influence; and bringing Islam back into the public sphere under the guise of Ottomanism" (p. 448).

In light of these arguments, when selecting programs with a neoOttomanist discourse we have categorized the programs under three themes. One of these themes has been Islam, our second theme has been Istanbul as the capital of the Empire, and our third theme has been Anatolian cultural heritage.

As one of its most prominent defining values, Islam is prevalent in the neo-Ottomanist discourse and can easily be traced to a number of programs broadcast in TRT Avaz such as Islamic Medicine, The Door of Benediction with Necmettin Nursaçan, Muslims of Russia, and A Warm 
Chat. In these programs, there is an emphasis on defining and celebrating the place of Islam in public life. Another prevalent defining value of the neo-Ottomanist ideology manifests itself as the exaltation of Istanbul as the Capital of the geography. In line with this discourse, it is possible to observe the following programs TRT Avaz broadcasts about the aggrandizing of Istanbul: The Last Emperor of the Three Continents, In the Footsteps of Sultans, Good Morning from Istanbul, and Cities of Istanbul. Finally, a third prominent neo-Ottomanist discourse clearly visible in the programs broadcast by TRT Avaz can be cited as the canonizing and ennobling of both the Ottoman Empire itself and the notion of Anatolian culture attached to it. The following are examples for such programs; Itinerary: In the Footsteps of Evliya Celebi, Foods of the Homeland, Common Heritage, Deep Roots, and Warm Faces of Anatolia. All these programs are geared towards focusing on perceived prominent people, places, values and cultural practices within Ottoman and Anatolian culture, norms and lifestyle.

As will be clear from the table above, the total of programs laden with neo-Ottomanist ideological discourse constitute a little over 30 hours per week. Some of these programs are repeated a number of times a day, while others are repeated throughout the week. The station broadcasts 24 hours a day, however, the night broadcasts are almost always repetitions of programs broadcast during day time. In this sense, active broadcasting of the station (broadcasts consisting of programs that are not repeated) can be thought as approximately 10 hours a day, which would sum up to 70 hours a week. Therefore, it would be safe to say that nearly $50 \%$ of the programs are those that deal with neo-Ottomanist content. The remaining $50 \%$ of the programs are constituted by news coverage in Turkish, Azeri, Kazak, Kırgiz, Üzbek, Türkmen and Russian languages (in total approximately 25 hours per week); and entertainment and magazine programs (approximately 15 hours per week). Since the entertainment programs and the news coverages are not explicitly charged by any particular ideology or agenda, one can argue that the general aura of the station is predominated by the 30 hours' worth of content geared towards the fostering of neo-Ottomanist cultural heritage.

\section{TRT El Arabia}

Initially founded as TRT-7-ET-Türkiyye in 2010, the channel changed its name to TRT El Arabia in 2015. It is stated on the website of the station that the channel was "established to reach 350 million Arab speaking viewers dispersed in and around the 22 countries located in the Arab region" (http://www.trtarabic.tv/). The mission of TRT El Arabia is announced as "establishing and strengthening relations and ties between 
the Arab nations and Turkey" (http://www.trtarabic.tv/). By targeting viewers, in Arabic, from every age, the channel "aims to be the common language, common feeling, and the common screen of the Arab world" (http://www.trtarabic.tv/).

Similar to the case of TRT Avaz, programs in TRT El Arabia can also be categorized under the same themes that are inherent in the neoOttomanist discourse. We can easily list the following programs under the theme of Islam: A Mosque a City, Wooden Mosques, Süleymaniye Mosque, and Life and the Koran. Istanbul as the capital of the Empire is a second theme under which programs can be categorized. Some such examples include: Istanbul the Ottoman Capital, Good Morning from Istanbul, Cities of Istanbul, Life in Istanbul, Min Istanbul, and Istanbul 5 Times a Day. Programs that can be listed under the category of Anatolian and Ottoman culture are: Ottoman Palaces, The Exile of the Ottoman Son, Africa and the Ottoman, Evliya Celebi, Mimar Sinan, Abdülhamid The Second, Hose Life in Anatolia, Flowers of Anatolia, and Time in Anatolia. In line with our categorizations, we claim that these can all be easily be cited as programs promoting the neo-Ottomanist discourse through TRT El Arabia.

The table below offers the schedule and screening times of the above cited programs that are screened in TRT-El Arabia. Similar to the case of our table concerning TRT Avaz, the table below also shows programs broadcast within a period of one week, between the dates 02.11.2016 and 08.11.2016.

\section{Table 2: Broadcast schedules of relevant programs in TRT EI Arabia}

\begin{tabular}{|c|c|c|c|c|c|c|c|}
\hline Program Names & 02.11 .2016 & 03.11 .2016 & 04.11 .2016 & 05.11 .2016 & 06.11 .2016 & 07.11 .2016 & 08.11 .2016 \\
\hline $\begin{array}{l}\text { Osmanlı Sarayları } \\
{ }^{*} \text { Ottoman Palaces }\end{array}$ & & $25 \min$ & & & $30 \mathrm{~min}$ & $30 \min$ & \\
\hline $\begin{array}{l}\text { Payitaht Osmanlı } \\
\text { Istanbul'u } \\
\text { *Istanbul the Ottoman } \\
\text { Capital } \\
\end{array}$ & & & $30 \mathrm{~min}$ & & & & \\
\hline $\begin{array}{l}\text { Osmanoğlu'nun Sürgünü } \\
\text { *The Exile of the Ottoman } \\
\text { Son }\end{array}$ & & & & 55 min & & & \\
\hline $\begin{array}{l}\text { Afrika ve Osmanlı } \\
\text { *Africa and the Ottoman }\end{array}$ & & & & $30 \mathrm{~min}$ & & & \\
\hline $\begin{array}{l}\text { Mimar Sinan } \\
{ }^{*} \text { Mimar Sinan }\end{array}$ & $25 \mathrm{~min}$ & $30 \mathrm{~min}$ & $30 \mathrm{~min}$ & $30 \mathrm{~min}$ & & & \\
\hline $\begin{array}{l}\text { Türk Kahvesi } \\
{ }^{*} \text { Turkish Coffee }\end{array}$ & & & $45 \mathrm{~min}$ & $45 \min$ & $50 \mathrm{~min}$ & & \\
\hline $\begin{array}{l}\text { Evliya Çelebi } \\
{ }^{*} \text { Evliya Çelebi }\end{array}$ & & & $30 \mathrm{~min}$ & & & & \\
\hline $\begin{array}{l}\text { 2. Abdülhamid } \\
\text { *Abdülhamid the Second }\end{array}$ & & & & $40 \mathrm{~min}$ & & & \\
\hline $\begin{array}{l}\text { İstanbul'dan Hayırlı } \\
\text { Sabahlar } \\
{ }^{*} \text { Good Morning from } \\
\text { Istanbul }\end{array}$ & $50 \mathrm{~min}$ & $50 \mathrm{~min}$ & & & $50 \mathrm{~min}$ & $50 \mathrm{~min}$ & $50 \mathrm{~min}$ \\
\hline
\end{tabular}




\begin{tabular}{|c|c|c|c|c|c|c|c|}
\hline $\begin{array}{l}\text { İstanbul'un Şehirleri } \\
{ }^{*} \text { Cities of Istanbul }\end{array}$ & & & $45 \mathrm{~min}$ & & & & \\
\hline $\begin{array}{l}\text { İstanbul'da Hayat } \\
\text { ^Life in Istanbul }\end{array}$ & & & $55 \mathrm{~min}$ & $30 \mathrm{~min}$ & & & \\
\hline $\begin{array}{l}\text { Min İstanbul } \\
{ }^{*} \text { Min Istanbul }\end{array}$ & & & & & $95 \mathrm{~min}$ & $90 \mathrm{~min}$ & \\
\hline $\begin{array}{l}\text { Bir Cami Bir Şehir } \\
{ }^{\star} \text { A Mosque, a City }\end{array}$ & $25 \min \times 4$ & $25 \min \times 3$ & $10 \mathrm{~min}$ & $10 \min \times 3$ & $25 \min \times 3$ & $25 \min \times 4$ & $25 \min \times 4$ \\
\hline $\begin{array}{l}\text { Ahşap Camiler } \\
\text { *Wooden Mosques }\end{array}$ & & $25 \mathrm{~min}$ & & & & & \\
\hline $\begin{array}{l}\text { Süleymaniye Camii } \\
\text { *The Süleymaniye } \\
\text { Mosque }\end{array}$ & & & $30 \min \times 2$ & & & & \\
\hline $\begin{array}{l}5 \text { Vakit İstanbul } \\
\text { *Istanbul } 5 \text { Times a Day }\end{array}$ & & & $30 \mathrm{~min}$ & & & & \\
\hline $\begin{array}{l}\text { İşte Hayat Işste Kuran } \\
\text { *Life and The Koran }\end{array}$ & & & $10 \mathrm{~min}$ & & & & \\
\hline $\begin{array}{l}\text { Anadolu'da Ev ve İnsan } \\
{ }^{*} \text { House life in Anatolia }\end{array}$ & $30 \mathrm{~min}$ & $30 \min \times 2$ & & $30 \mathrm{~min}$ & $30 \min \times 2$ & $30 \min \times 2$ & $30 \mathrm{~min}$ \\
\hline $\begin{array}{l}\text { Anadolu Çiçekleri } \\
{ }^{\star} \text { Flowers of Anatolia }\end{array}$ & $30 \min \times 2$ & $30 \mathrm{~min}$ & & $30 \mathrm{~min}$ & $30 \min \times 2$ & $30 \min \times 2$ & $30 \min \times 2$ \\
\hline $\begin{array}{l}\text { Anadolu'da Zaman } \\
\text { *Time in Anatolia }\end{array}$ & & & & $30 \mathrm{~min}$ & & & \\
\hline Total Duration & $220 \mathrm{~min}$ & $280 \mathrm{~min}$ & $345 \mathrm{~min}$ & $350 \mathrm{~min}$ & $390 \mathrm{~min}$ & $345 \mathrm{~min}$ & $195 \mathrm{~min}$ \\
\hline
\end{tabular}

Again, like Table 1, Table 2 shows us that the total duration of relevant programs broadcast over a period of one week is a little over 30 hours. 30 hours amount to substantial screen time. Despite the broadcast being 24 hours a day, the hours between 11:00PM and 9:00AM are usually covered with repetitions of programs broadcast during the day time, similar to the case of TRT Avaz. These numbers and the content of the programs become even more meaningful when they are juxtaposed with the remainder of the programs screened in these channels. Approximately 45 hours per week of the daytime broadcasts are allocated to news, magazine programs and entertainment programs. Programs that revolve around issues of national culture (as one would expect from a public service broadcaster) as opposed to neo-Ottomanism as a perceived transnational collectivity are extremely rare. In this sense, the station ends up allocating approximately $45 \%$ of its broadcast time to programs engaging with the discourse of neo-Ottomanism. We argue that this again is a clear demonstration of the transnational nature of both TRT Avzaz and TRT El Arabia.

In addition to the quantitative tables above showing the schedules and durations of the programs broadcast in TRT Avaz and TRT El Arabia, and the percentages of the programs broadcast, below we offer a brief snippet of some representative programs from the channel. We believe looking at the official descriptions of these programs and elaborating briefly on their content, will help better carry our arguments to the point that TRT Avaz and TRT El Arabia are being mobilized by the JDP 
government to disseminate a neo-Ottomanist heritage to the relevant geographies.

\section{Sultanların Izinde (In the Footsteps of the Sultans)}

This is a short documentary-like program that is broadcast four days a week, every episode lasting from 15 to 30 minutes. In each episode, the program focuses on one of the Sultans of the Ottoman Empire and his achievements. In the official description of the program is stated as follows: "A small chiefdom that came to being in Northwest Anatolia towards the end of the $13^{\text {th }}$ Century has in a short period of time become a huge state that covers the three quarters of Anatolia and the lands ranging from Serbia to Moldova in the Balkans. In the following centuries, gaining control over large lands in Asia, Europe and Africa, this state has brought about a grand civilization. How such a small chiefdom has come to be one of the greatest states of the world is a question still intriguing historians. There can only be one answer; the Ottoman Empire is not an empire per se, but the existence of a civilization on every scale. This program narrates the story of this civilization".

\section{Üç Kıtanın Son Hükümdarı (The Last Emperor of the Three Continents)}

This program is a documentary about the Sultan Abdülhamid The Second. It is broadcast once a week and consists of six 40 minute episodes. The official description of the program states: "This is a six-episode documentary about the life of Sultan Abdülhamid the Second who was the $34^{\text {th }}$ Sultan of the Ottoman Empire and the $113^{\text {th }}$ Caliphate of Islam. The documentary is the result of three years of meticulous research including the Ottoman State Archives, IRCICA and the Russian State Archives. The documentary also draws on interviews with historians renown around the world and Turkey".

Seyahatname: Evliya Çelebi'nin İinde (Travel Notes: In the footsteps of Evliya Çelebi)

This is a 30 minute documentary program broadcast twice a week. Each episode is 30 minutes and focuses on a selected geography from the travel notes of the famous Ottoman wanderer Evliya Çelebi. The official description states: "Evliya Çelebi, the most famous wanderer of all times... spent 51 years travelling, wandering, exploring Ottoman territories in the $17^{\text {th }}$ Century. The life and stories of Evliya Çelebi is brought to you by TRT Avaz".

\section{Derin Kökler (Deep Roots)}

Deep Roots is a short magazine-documentary program. The program lasts for only five minutes but is repeatedly broadcast five days a week, four 
times each day. The content of the documentary changes in each episode but the overarching theme is about preserving and rejuvenating Ottoman and Anatolian cultural and historical traditions. The official description states, "It is not only gardens and fields that need to be preserved, nurtured and transferred to future generations. The real heritage and legacy that needs to be passed on to future generations is a rich culture of traditions consisting of songs, games, stories and poems. Deep Roots program travels through Anatolia to remember, preserve and transfer these regional traditions to future generations".

\section{Tıbb-I Nebevi (Islamic Medicine)}

This is a documentary program broadcast once a week. Each episode is 30 minutes and looks at the ways in which Islam and the Prophet Muhammed approach medicine, and gives advice on traditional Islamic "alternative" medicine. The official description states, "On TRT Avaz screens, the secrets of a healthy, happy, and peaceful life through Islamic medicine are being discovered. The program focuses on the importance of Islam and our Prophet, giving healthy treasures found in nature and examples from Islamic medicine".

\section{Ortak Miras (Common Herritage)}

Broadcast once a week, Common Herritage is a 30 minute documentary focusing each week on a select common cultural tradition among Turkic Republics ranging from Kazakhstan to Bulgaria, Azerbaijan and Macedonia.

In line with our analysis of the program content and the mission and vision statements of TRT Avaz and TRT El Arabia, we argue that these two stations have become transnational agents of the JDP government. This is an intriguing phenomenon in that TRT is no longer concerned solely with nationalizing or modernizing its viewers within the national borders of Turkey, as it has done for nearly half a century. Nor is it concerned with disseminating the "secular", "modern", "nationalist" cultural values that have been held dear by the Turkish state since its establishment. Both approaches may have been the expected broadcasting politics from a public service broadcaster. What TRT is doing instead is expanding its reach to an imagined transnational audience with a transnational message - the case being that neither the audience nor the message are necessarily national. TRT Avaz and TRT El Arabia are formulating a transnational communality based on neo-Ottomanist culture, history and norms, none of which are formally spelled out or pronounced in any of the formal institutions of the nation-state. 
We have suggested that an international broadcasting agenda started becoming apparent in TRT during the 1990s with expansions such as TRT INT, TRT Avrasya and TRT Türk. This agenda cannot be comprehensively analyzed independent of the rise of neo-Ottomanism under Özal's rule. However, a dramatic rupture in TRT's vision (and mission) started taking form at the beginning of 2010. We have argued that TRT has embarked on a new mission - to broadcast transnationally to Arabic speaking and Islamic populations dispersed within and around the Middle East. We argue that a realignment of political power in Turkey during the 2000s has allowed for a political party to come to power and bring with it its own side-itinerary in the form of neo-Ottomanism. This "side-itinerary" contradicted with modern Turkey's prevalent West-facing facing national agenda. This rift resulted in the emergence of a transnational component within TRT, as its broadcast politics were now in line with JDP's claims to regional power in the MENA region, which previously had not lined up with the century-long national ideals of modern Turkey (Kaptan and Karanfil 2013). TRT Avaz and TRT El Arabia, understood the advantages of a transnational media ecologies in evidence around the world. Now they are excellent examples of the ways in which JDP deployed the public service broadcaster of Turkey to disseminate its transnational agenda and to exert a form of soft power in the MENA region.

In sum, we have claimed that the emergence of this transnational agenda of TRT was not a coincidence but rather an outcome of the historical concurrence of two phenomena. One of these, we argued, was the gaining of prominence of neo-Ottomanism as a cultural and political tool, to be deployed both within and across the borders of Turkey, under the rule of JDP. The other was the relatively recent development in the information and communication technologies, resulting in a transformation in the global media spheres - namely, the transnationalization of broadcasting. In other words, we show the ways in which developments in the political and cultural dynamics on a global and national level alongside the revival of neo-Ottomanism in Turkish foreign cultural policy have formed one of the layers through which we can understand the transnationalization of TRT. The argument claims that the JDP government has mobilized TRT to serve its needs in realizing its neoOttomanist agenda as a newly emergent initiative in its neighboring geographies. Further, that it is possible to trace a correlation between the spheres of politics, culture and broadcasting in this respect. However, we have also argued that trying to explain the changing dynamics in TRT's broadcasts simply through this optic would have its shortcomings. Our 
second claim therefore has been that, it was the changing global media environment, more specifically the transnationalization of broadcasting, that made TRT's transformation possible. In sum, by means of tracing the correlations between the spheres of politics, culture and media in Turkey, we have attempted in this article to show how TRT El Arabia and TRT Avaz have been mobilized by the JDP government to disseminate neoOttomanism in the perceived hinterlands of the former Ottoman Empire. 


\section{References}

Aksoy, Asu and Kevin Robins (2000), "Thinking Across spaces: Transnational Television from Turkey", European Journal of Cultural Studies, 3 (3), 343-65.

Aksoy, Asu and Kevin Robins (2003), "Banal Transnationalism: The Difference that Television Makes", in The Media of Diaspora, K.H. Karim, ed. London: Routledge, 89-104.

Alankuş, Sevda and Eylem Yanardağoğlu (2016), "Vacillation in Turkey's Popular Global TV Exports: Toward a More Complex Understanding of Distribution", International Journal of Communication, 10 (2016), 3615-31.

Al-Ghazi, Orhan and Marwan Kraidy (2013), "Neo-Ottoman Cool 2: Turkish Nation Branding and Arabic-Language Transnational Broadcasting", International Journal of Communication, 7 (2013), 2341-60.

Altunışık, Benli Meliha (2008), "The Possibilities and Limits of Turkey's Soft Power in the Middle East," Insight Turkey, 10 (2), 41-54.

Altunışık, Benli Meliha (2009), "Worldviews and Turkish foreign policy in the Middle East", New Perspectives on Turkey, 40, 169-92.

Buccianti, Alexandra (2010), "Dubbed Turkish Soap Operas in the Arab World: Social Liberation or Cultural Alienation?" Arab Media \& Society, March 30.

Chalaby, Jean (2003), "Television for a New Global Order: Transnational Television Networks and the Formation of Global Networks", Gazette: The International Journal of Communication Studies, 65 (6), 457-72.

Chalaby, Jean (2005), "From Internationalization to Transnationalization", Global Media and Communication, 1 (1), 28-33.

Christensen, Miyase (2013a), "New Media Geographies and the Middle East", Television and New Media, 14 (4), 267-70.

Christensen, Miyase (2013b), "TransNational Media Flows: Some Key Questions and Debates", International Journal of Communication, 7 (2013), 2400-18.

Christensen Miyase and Andre Jansson (2013), Cosmopolitansim and the Media: Cartographies of Change, Basingstoke: Palgrave Macmillan. 
Cunningham, Stuart and John Sinclair John, eds. (2000), Floating lives: The Media and Asian Diasporas. Brisbane, Australia: University of Queensland Press.

Çaplı, Bülent (1996), Televizyon ve Siyasal Sistem, Ankara, Turkey: Imge Kitabevi Yayınları.

Çolak, Yılmaz (2006), "Ottomanism vs. Kemalism: Collective Memory and Cultural Pluralism in 1990s Turkey", Middle Eastern Studies, 42 (4), 591-95.

Dholakia, Nikhilesh and Deniz Atik (2016), "Markets, Globalization and Development: Charting the Intersections of three Multipolar Concepts", Markets, Globalization and Development Review, 1 (1), 1-10.

Davutoğlu, Ahmet (2010), Stratejik Derinlik, Türkiye'nin Uluslararası Konumu. İstanbul: Küre Yayınları.

Fisher-Onar, Nora (2011), "Constructing Turkey Inc.: The Discursive Anatomy of a Domestic and Foreign Policy Agenda", Journal of Contemporary European Studies, 19 (4), 463-73.

Kaptan, Yeşim and Gökçen Karanfil (2013), "RTÜK, Broadcasting, and the Middle East: Regulating the Transnational", International Journal of Communication, 7 (2013), 2322-40.

Karanfil, Gökçen (2011), "Medya ve Diyaspora: Türkiye'de Ulusaşırı Yayıncılığın Dinamikleri”, Kültür ve Illetişim, 14 (1), 37-69.

Karim, Karim (1998), "From Ethnic Media to Global Media: Transnational Communication Networks Among Diasporic Communities", paper presented at the Transnational Communities Programme Working Paper Series, WPTC-99-02.

Kerslake, Celia, Kerem Öktem and Philip Robins, eds. (2010), Turkey's Engagement with Modernity, Conflict and Change in the Twentieth Century, London: Pelgrave McMillan.

Kraidy, Marwan and Orhan Al-Ghazzi (2013), "Neo-Ottoman Cool: Turkish Popular Culture in the Arab Public Sphere", Popular Communication: The International Journal of Media and Culture, 11 (1), 17-29.

Naficy, Hamid (1993), The Making of Exile Cultures: Iranian Television in Los Angles, Minneapolis, MN: University of Minnesota Press.

Oğuzlu, Tarık (2007), "Soft Power in Turkish Foreign Policy", Australian 
Journal of International Affairs, 61(1), 81-97.

Oğuzlu, Tarık (2008), "Middle Easternization of Turkey's Foreign Policy: Does Turkey Dissociate from the West?, Turkish Studies 9 (1), 3-20.

Öniş, Ziya (2011), "Multiple Faces of the "New" Turkish Foreign Policy: Underlying Dynamics and a Critique," Insight Turkey, 13 (1), 47-65.

Panagakos, Anastasia and Heather Horst (2006), "Return to Cyberia: Technology and the social worlds of transnational migrants", Global Networks, 6 (2), 109-24.

Sinclair, John (1997), "The Decentring of Cultural Imperialism, Televisation and Globo-ization in the Latin World", in Media and Cultural Regulation, Thompson, K. ed. London, UK: SAGE Publications, 120-34.

Straubhaar, John (1997), "Distinguishing the Global, Regional and National Levels of World Television", in Media in Global Context: A Reader, A. Sreberny-Mohammadi, A., Winseck, D., McKenna J, and Boyd-Barrett, O. eds. London, UK: Arnold, 284-98.

Vertovec, Steven (2001), "Transnationalism and Identity", Journal of Ethnic and Migration Studies, 27 (4), 573-82.

Vertovec, Steven (2009), Transnationalism, Abingdon: Routledge.

Yanardagoglu, Eylem, and Imad Karam (2013), "The Fever that Hit Arab Satellite Television: Audience Perceptions of the Turkish TV series", Identities: Global Studies in Culture and Power, 20 (5), 561-79.

Yanık, Lerna K. (2011), “Constructing Turkish 'exceptionalism': Discourses of liminality and hybridity in post-Cold War Turkish foreign policy", Political Geography, 30, 80-89.

Yavuz, Hakan (1998) "Turkish Identity and Foreign Policy in Flux: The Rise of Neo-Ottomanism", Critique: Critical Middle Eastern Studies, 7 (12), 19-41.

Yavuz, Hakan (2016), "Social and Intellectual Origins of Neo-Ottomanism: Searching for a Post-National Vision", Die Welt Des Islams 56, 43865.

Yörük, Zafer and Pantelis Vatikiotis (2013), "Soft Power or Illusion of Hegemony: The Case of the Turkish Soap Opera "Colonialism"', International Journal of Communication, 7 (2013), 2361-85. 